\title{
Loan growth and interest income of Italian listed banks: a multivariate analysis
}

\section{Chiara Crovini ${ }^{*}$, Giovanni Ossola and Guido Giovando}

Department of Management,

School of Management and Economics,

University of Turin,

C.so Unione Sovietica 218/bis,

10134, Turin, Italy

Email: chiara.crovini@unito.it

Email: giovanni.ossola@unito.it

Email: guido.giovando@unito.it

*Corresponding author

\begin{abstract}
This study focuses on the relationship between gross loans and the related reserves for impaired loans of the banks listed on the Italian Stock Exchange between 2005 and 2014. In our empirical research, we analysed the trend of those items and we also concentrated on the impact of net loans on total assets. Afterwards we monitored the correlation between loan growth, bank solvency, loan losses and the interest income of each bank in order to analyse the impact on the profitability of the banks and evaluate the effects of a specific loan policy. Finally, we concentrated on the multivariate linear regression whose dependent variable is the variation of the interest income between 2013 and 2014. Our research raises important issues on the necessary policy supervision in terms of risk management because, thanks to our analysis, we underline the strategic role of loan growth and its impact on the economic profitability of Italian listed banks.
\end{abstract}

Keywords: banks; loan growth; impaired loans; interest income; multivariate regression; MANOVA.

Reference to this paper should be made as follows: Crovini, C., Ossola, G. and Giovando, G. (2016) 'Loan growth and interest income of Italian listed banks: a multivariate analysis', Int. J. Markets and Business Systems, Vol. 2, No. 2, pp.85-101.

Biographical notes: Chiara Crovini is a $\mathrm{PhD}$ candidate in Business and Management at the Department of Management, University of Turin, Italy. Her research area covers all the topics related to corporate governance, internal control systems, internal auditing, statutory audit of SMEs, banks and credit institutions. She is a member of Accademia Italiana di Economia Aziendale Giovani (AIDEA Giovani).

Giovanni Ossola is a Full Professor in Business Administration at the Department of Management, University of Turin, Italy. Currently, he is teaching business administration in the bachelor degree courses and financial accounting and financial statements of banks and credit institutions in the master degree courses. He is a Chartered Accountant and Statutory Auditor in many companies. He is a member of Accademia Italiana di Economia 
Aziendale (AIDEA). He is the author of many national and international publications in the banking and assurance field, financial accounting and airport infrastructure.

Guido Giovando is an Associate Professor in Business Administration at the Department of Management, University of Turin, Italy. Currently, he is teaching business administration and cost accounting in the bachelor degree courses and accounting and financial statements of banks and credit institutions in the master degree courses. He is a Chartered Accountant and Statutory Auditor in many companies. He is the author of many national and international publications in the banking and assurance field, financial accounting and airport infrastructure. He is an Associate EuroMed Academy of Business (EMAB) Fellow of the EuroMed Academy of Business (EMAB).

This paper is a revised and expanded version of a paper entitled 'Banks' gross loans listed on the Italian Stock Exchange' presented at The Eighth Annual Conference of the Euromed Academy of Business, 'Innovation, Entrepreneurship and Sustainable Value Chain in a Dynamic Environment', University of Verona, Italy, 16-18 September 2015.

\section{Introduction}

Banks, like any other businesses, have been changing continuously with the surrounding environment. In fact, there are several inputs, such as production factors, constraints and conditions that, through a process of transformation, generate a series of outputs (Ferrero, 1987). Along with insurance companies and financial intermediaries, banks are part of the so-called 'financial system' (Giovando and Venuti, 2014). The financial system connects the entire economic system through the financial reports (Onado, 2000).

The financial statements of banks present peculiarities of composition, exposure and content which are typical of that specific type of business (Bocchino et al., 2013). Indeed the bank balance sheet follows an order of presentation of the items, which is essentially based on a policy of decreasing liquidity, with cash and cash equivalents reported as the first entry (Giovando and Venuti, 2014).

Our empirical study bases its theoretical rationale on the necessity to strengthen with further demonstrations the importance and the strategic role of loans and the several implications of a specific loan policy on the profitability of each bank.

By analysing several works of many researchers, we started our research with a very complex theoretical framework.

Therefore our research focuses at first on the analysis of loans. In fact loans are an essential item of the balance sheet of banks, as being one of the most representative items heavily influencing both stability and profitability of this system.

Periodically, loans are subjected to verification for possible quality deterioration (impairment test), which is understood as a possible value loss. The reasons and the circumstances that may lead to an impairment of the financial asset are indicated in IAS 39 (Busso, 2014).

In accordance with the provisions laid down by the supervisory board and in line with the IAS/IFRS, the procedure of 'impairment' requires, therefore, to divide the credits into two large groups: exposures (the so-called 'non-performing loans') and those that do not 
bring individually to objective evidence of impairment (performing loans or 'performing').

The International Accounting Standards aim at giving a true and fair representation of the above-mentioned item. Finally, in order to define the adjustment and the associated value loss, we proceed by deleting the receivables for which the impairment is considered complete and definitive or devaluing (individually or collectively, depending on the method applied) claims for which it is made a necessary rectification.

For these reasons, we want to analyse the amount of loans to customers and their allowances for doubtful accounts of a sample of banks listed on the stock market.

By starting with the first hypothesis that the assets of banks listed on the sectoral index called FTSE banks are mainly represented by loans, our first aim is to study the trend of gross loans and the related reserves for impaired loans in the period between 2005 and 2014. Consequently, we firstly want to demonstrate that the amount of net loans is particularly significant in bank balance sheets. Afterwards with reference to our second hypothesis and to the concept that there is a negative correlation between loan growth and the profitability of a bank in terms of interest income, we calculate the Pearson correlation ratio between loan growth, bank solvency and loan losses and the interest income of each bank. Thanks to this ratio, we can analyse the impact of those three items on the profitability of the banks of the sample in order to evaluate the effects of a specific gross loans policy. In the third part, we concentrate on the multivariate linear regression (MANOVA - multivariate) analysis of variance, whose dependent variable is the variation of the interest income between 2013 and 2014.

Finally we explain our conclusions.

This research differs from previous studies in terms of empirical analysis. First of all, its originality lies in the choice of the sample, which is particularly representative as it includes all the companies of the bank sector, listed on the Italian stock market. In addition, the first part of our study was conducted over a very long period.

Another element of originality is the attempt to underline the strategic role of loan growth and its impact on the profitability of the banks of the sample between 2013 and 2014, by monitoring the correlation between loan growth, bank solvency and loan losses and the interest income and the multivariate analysis of regression.

Therefore this research allowed us to see the changes in the items considered and to follow the evolution that occurred in that period. Moreover, in those years there was a very important global crisis that particularly affected the financial sector and consequently those companies operating in our market.

There are some limits in this research: first of all we should underline that this is the second phase of a far deeper analysis on the banking system that can consider other variables, financial indicators and margins. We decided not to implement a complex multivariate model because we aimed at pursuing the effectiveness of the results and concentrating on the real relationship between the items considered. The same analysis can be extended to other banks belonging to different countries with the aim to compare and contrast the Italian situation with that of other realities. In addition, it could be interesting to extend the MANOVA analysis of regression to other years in order to evaluate the inter-temporal relationship of the variables implied in our study.

The remainder of this study is organised as follows. In Section 2, we provide the literature review of the topic presented. The definition of the sample of companies and the methodology are described in Section 3. In this section, we also include the 
presentation of the research questions and of the phases of analysis. Our findings are presented in Section 4. Discussions are in Section 5 and conclusions in the last part of the research.

\section{Literature}

Many analyses were conducted to study the bank in its entirety (Koch and MacDonald, 2007; Ossola, 2005; Giovando and Gianoglio, 1999; Giovando, 1996). During the past few decades, many scholars have studied the bank account (Bocchino et al., 2013; Ossola, 2005), its performance (Barros et al., 2007; Berger, 2005; Boubakri et al., 2005) and its financial analysis (Hartvigsen, 1992). Some researchers analysed the performance of banks belonging to individual countries (Faisal and Farzand, 2015; Iqbal and Raza, 2009; Ali and Ansari, 2007; Barros et al., 2007). Recent studies concentrated on the accounting policy of banks, focusing on the application of the International Accounting Standards (Dezzani et al., 2014) and other specific studies focused on the analysis of the assets and liabilities of the balance sheets (Ossola, 2000).

In addition other researchers have recently analysed the impact of the new capital requirements under Basel III on bank lending rates and loan growth (Kahlert and Wagner, 2015). As a result higher capital requirements, raising the marginal cost of bank funding, have led to higher rates (Cosimano and Hakura, 2011; Elliott, 2009; Laeven and Valencia, 2008).

Some studies focused on the way some financial entities have addressed this moment of global crisis (Crowley, 2015; Navajas and Thegeya, 2013; Avdjie et al., 2012; Caprio et al., 2011). Many researchers concentrated on this period of financial crisis, highlighting the crucial role played by the liquidity risk in the stability of a bank, and, more generally, in the financial system (Borio, 2008; Dell'Ariccia et al., 2008; Strahanb and Cebenoyan, 2004). Some have tried to locate the perimeter within which identify the financial risk and study methods for good management, in accordance with the requirements of Basel (Álvarez and Rossignolo, 2015; Angelini et al., 2011).

A major study found that the systemically important banks of the eurozone, during the period between 2007 and 2013, were well capitalised with respect to market risk, but they were undercapitalised with respect to the credit and counterparty risks (Kahlert et al., 2015).

The accumulation of reserves in the banking system of the USA during the financial crisis increased concerns that the policies of the Federal Reserve may have failed to stimulate the flow of credit to the economy: banks, apparently, were accumulating funds instead of lending money (Keister and McAndrews, 2009).

Although credit risk is an important factor that financial institutions should cope with, loans have been little studied.

A smaller proportion of studies focused on loans in the bank balance sheet. In particular some scholars employ Granger-causality techniques to test four hypotheses regarding the relationships among loan quality, cost efficiency and bank capital (Berger and de Young, 1997). Other studies analysed the trade-off between loan portfolio composition and diversification, using a unique dataset that is able to identify individual bank loan exposures to different industries, sectors and to different geographical areas (Acharya et al., 2003). Some studies have analysed the different types of customer loans 
and they compared and contrasted the situation of credit lending of different regions (Salas and Saurina, 2002).

Early empirical studies concentrated deeply on the relationship between loan growth and loan losses. Sinkey and Greenwalt (1991) analysed large US banks during the period between 1984 and 1987 and they found that the average past loan growth was significantly positively related to the contemporaneous loan loss rate. Another researcher (Clair, 1992), instead, concentrated on data of individual banks from Texas during the period between 1976 and 1990 and detected a negative impact of loan growth on non-performing loans and the loan charge-off rate for the first year after a bank's credit expansion, whereas for subsequent years, a positive relation could partly be found. Berger and Udell (2004) examined the procyclicality of bank lending in the USA during 1980-2000. They found that credit standards were relaxed and more loans were granted.

The determinants of loan losses were also studied at the international level and in countries outside the USA. Laeven and Majnoni (2003) analysed Bankscope data from forty-five countries to shed light on factors influencing the loan loss provisioning and income smoothing of more than 1,000 large commercial banks during the period between 1988 and 1999. It turned out that banks provisioned too little in good times of the cycle and were forced to overreact during period of crisis. They also detected a significantly negative contemporary relation between loan growth and loan losses, suggesting an imprudent provisioning behaviour of banks. Similarly, Bikker and Metzemakers (2005) examined the contemporary relation between loan loss provisioning of individual commercial banks and the business cycle during the period between 1991 and 2001. They based their study on Bankscope data of OECD countries and they found a negative relation between GDP growth and loan loss provisioning.

Other researchers (Salas and Saurina, 2002) instead analysed a large dataset from Spanish commercial and savings banks in the period between 1985 and 1997. They found that loan growth of savings was significantly positively associated with loan losses of the previous three or four years.

Iannotta et al. (2007) as well as Illueca et al. (2008) documented that bank ownership is an important determinant of lending behaviour, risk taking and performance.

Finally, there were studies that analysed the relationship between loan growth and banking crises in transition economies and developing countries (Cottarelli et al., 2005; Kraft and Jankov, 2005).

Important studies concentrated deeply on how loan growth affects the riskiness of individual banks in many countries (Bushman and Williams, 2012; Foos et al., 2010). Foos et al., by using three different multivariate regression models, underlined that loan growth lead to an increase in provisions for credit losses over the following three years, to a decrease in the related interest income and lower capital ratios. Further analysis showed that lending growth had also a negative impact on the risk-adjusted net interest income. All these findings lead to the conclusion that loan growth is an important driver of the riskiness of banks.

However, none of the above-mentioned previous studies concentrated specifically on Italian banking firms for a very long period. In fact, our research covers the period between 2005 and 2014. In addition, we considered all banks listed on the Italian Stock Exchange, which represent more than $80 \%$ of the entire Italian financial system. Moreover, we did not implement a sophisticated statistical model in order to pursue the effectiveness of the results and to concentrate on the real relationship between the items 
considered. However, thanks to our multivariate analysis, we tried to find a relation between loan growth, bank solvency, by using the equity-to-total asset ratio, loan loss provisions and the profitability of the banks of the sample. Consequently, we wanted to improve one of Foos et al.'s model in order to adapt it to Italian listed banks.

Our approach is balance-sheet-based, consequently we started from the data extracted from Bankscope database and consequently from the financial statements of banks. However, despite the limits of the research, thanks to this analysis and the results obtained, we may consider the opportunities of growth and development of our analysis.

In conclusion, one of the aims of this research is to improve the existing literature by using an empirical approach.

\section{Methodology}

The following paragraphs describe the sample and the methodology followed to conduct our research.

\subsection{The sample and the data}

This analysis focuses on the group of banks listed on the Italian Stock Exchange. In particular, we chose those listed on the sectoral index called FTSE Banks. We decided to exclude Banca Popolare dell'Etruria because it went bankrupt. In this group of banks, we focused on the analysis of the gross loans and the related reserves for impaired loans in the period between 2005 and 2014. Moreover this study can help us understand the context and the main business in which banks operate. Data were extracted from Bankscope, which is a database containing comprehensive information on financial companies (banks and insurance companies) in Italy. We used the consolidated balance sheets of all companies and, in the first part of phase 2 , we focused on information about gross loans, reserves for impaired loans and total assets of the balance sheet of the groups of banks companies.

We want to specify that data provided in our figures all refer to the mean of the single element analysed.

In the second part, regarding the multivariate analysis, we concentrated on some ratios, such as equity to total assets and interest income on loans/average gross loans, and on the loan loss provisions, provided by Bankscope.

Table 1 shows all the Italian banks of the sample analysed.

\subsection{Research questions and phases of analysis}

The present research is based on the following hypotheses:

- H1: The assets of banks listed on the sectoral index called FTSE Banks are mainly represented by loans.

- H2: There is a negative correlation between loan growth and interest income. 
Table 1 Italian listed banks of the sample

\begin{tabular}{l} 
Banks \\
\hline Banca Finnat Euramerica SpA \\
Banca Popolare di Milano SCaRL \\
Banca Popolare di Sondrio Societa Cooperativa per Azioni \\
Banca popolare dell'Emilia Romagna \\
Banca Profilo SpA \\
Banco di Desio e della Brianza SpA-Banco Desio \\
Banco di Sardegna SpA \\
Banco Popolare - Società Cooperativa-Banco Popolare \\
Banca Carige SpA \\
Credito Emiliano SpA-CREDEM \\
Banca Piccolo Credito Valtellinese-Credito Valtellinese Soc Coop \\
FinecoBank Banca FinEco SpA-Banca FinEco SpA \\
Intesa Sanpaolo SpA \\
Mediobanca SpA-MEDIOBANCA - Banca di Credito Finanziario Società per Azioni \\
Banca Monte dei Paschi di Siena SpA-Gruppo Monte dei Paschi di Siena \\
Unione di Banche Italiane Scpa-UBI Banca \\
UniCredit SpA
\end{tabular}

To reach the goals of this study, we need to formulate two research questions:

- RQ1: What is the role of net loans for banks in terms of impact on total assets? And, consequently, what is the trend of gross loans and the reserves for impaired loans?

- $R Q 2$ : Is there a correlation between loan growth, bank solvency and loan losses and the profitability of a bank, in terms of interest income?

- $\quad$ RQ3: can a generalised model of multivariate linear regression explain the relationship between loan growth, bank solvency and loan losses and the variation of interest income in the period between 2013 and 2014 ?

The research methodology follows three phases:

a Phase 1: Definition of the items monitored. As we analyse the annual financial reporting of a group of Italian listed companies, we refer to the IAS-IFRS principles (Dezzani et al., 2014), and in particular to IAS 1, Presentation of financial statement.

b Phase 2: Empirical analysis and findings. It involves an analysis of the information derived from the sample. The research methodology only uses the information provided in the consolidated financial statements because it is sufficient to answer the research questions.

With reference to $R Q 1$, we firstly want to demonstrate that the amount of net loans is particularly significant in bank balance sheets. Afterwards we want to monitor their evolution and make a comparison with the percentage of reserves of impaired loans to the total gross loans in the period considered. 
With reference to $R Q 2$, we firstly calculate the Pearson correlation ratio between loan growth, bank solvency and loan losses and the interest income of each bank. Thanks to this ratio, we can analyse the impact of those three items on the profitability of the banks of the sample in order to evaluate the effects of a specific gross loans policy.

As mentioned above, the Pearson correlation ratio (p) is used to identify a positive or negative correlation between the gross loans and the reserves for impaired loans. For this, it is necessary to underline the following conditions:

- if $\mathrm{p}>0$ there is a direct correlation

- if $\mathrm{p}=0$ there is no correlation

- if $\mathrm{p}<0$ there is a indirect correlation

- if $0<\mathrm{p}<0.3$ the correlation is weak

- if $0.3<\mathrm{p}<0.7$ the correlation is moderate

- if $\mathrm{p}>0.7$ the correlation is strong.

With reference to $R Q 3$, we used a generalised econometric model of a multivariate linear regression, whose dependent variable is the variation of the interest income between 2013 and 2014.

c Phase 3: Conclusions and limitations of the research.

\subsection{Statistical techniques}

In phase 2, after a brief analysis of the data obtained and a descriptive statistics, we conducted a multivariate analysis of variance (MANOVA), using a software, called SPSS. This analysis refers to 2014.

Foos et al. (2010) elaborated three different models, regarding the relationship between loan losses, interest income and bank solvency with loan growth.

Our analysis instead concentrates on the impact of loan growth, bank solvency and loan losses on the variation of interest income between 2013 and 2014. We decided to study the dependence and the role of a combination of ratios and items reported in the balance sheets and in the income statements of all banks of the sample.

We did not implement a sophisticated statistical model in order to pursue the effectiveness of the results and to concentrate on the real relationship between the items considered.

The estimated model is:

$$
\Delta R I I_{i, t}=\alpha+\beta_{1} L G_{i, t}+\beta_{2} E Q . A S S_{\cdot i, t}+\beta_{3} L n L L P_{i, t}+\varepsilon_{i, t}
$$

The dependent variable is the variation of the relative interest income $\left(\Delta R I I_{i, t}\right)$, defined as the difference between the relative interest income in the period between 2013 and 2014. The $R I I$ is the fraction of total interest income on loans over total customer loans.

Loan growth $\left(L G_{i, t}\right)$ is the percentage change in the amount of bank $i$ 's gross loans from year $t-1$ to year $t$. In our study, we monitored the variation between 2013 and 2014.

We considered gross loans in order to avoid every distortion linked to the risk of considering twice the reserves for impaired loans and the related losses. 
The equity-to-total assets ratio $\left(E Q \cdot A S S_{i, t}\right)$ represents the bank solvency and consequently the bank ability to face any economic and financial crisis.

During the past two decades both risk management in banking and prudential regulations concerning banking risk exposure evolved significantly. In addition, with Basel II and the new Basel III capital framework, banks are required to meet a minimum capital ratio in order to be able to face potential risks, such as credit, operational and market risks.

The last explanatory variable is the loan loss provisions reported in the income statement of all banks. We normalised the item, by using the natural logarithm $\left(\operatorname{Ln} L L P_{i, t}\right)$.

In our analysis we compared losses registered in 2014 with the variation of the interest income between 2013 and 2014 in order to evaluate the real impact on the profitability of banks.

Table 2 summarises the main variables used in the above-mentioned model and the related descriptive statistics.

Table 2 The main variables of the multivariate regression model

\begin{tabular}{lcccccc}
\hline Variable & Notation & Mean & Median & Std. dev. & Min. & Max. \\
\hline Relative interest income (\%) & RII & 3.22 & 3.3 & 0.809 & 0.85 & 4.39 \\
Loan growth (\%) & LG & 0.02 & -0.01 & 0.136 & -0.176 & 0.395 \\
Equity-to-total assets ratio (\%) & EQ.ASS. & 7.945 & 7.03 & 3.364 & 3.26 & 17.27 \\
$\begin{array}{l}\text { Natural logarithm of loan loss } \\
\text { provisions }\end{array}$ & Ln LLP & 5.65 & 6.16 & 2.737 & 0.095 & 9.026 \\
\hline
\end{tabular}

\section{Findings}

First of all, before analysing the data obtained, we want to give further details and definitions.

The gross loans include loans, finance leases, factoring transactions, debt securities, the variation margins with clearing in front of derivative transactions and operating receivables associated with the provision of financial services.

The gross loans are initially recognised at fair value which corresponds to the amount disbursed, or subscription price, plus any transaction costs and revenues directly attributable.

At the end of each accounting period the entire loan portfolio is assessed for loss of value.

The amount of the loss is recognised in the income statement.

The evaluation of the impairment loss on the entire loan portfolio is made by taking into account these distinctions:

- non-performing loans (non-performing): this category includes the suffering, substandard loans, restructured loans, loans past due/overdue (past due), as defined by the applicable regulatory reporting

- $\quad$ performing loans (or performing): as for non-performing loans (excluding past due) assessment, analytically attributed to each individual position, is performed, for loans 
that exceed the threshold of significance, determining the expected cash flows and the relative timing of receipts.

Phase 2 concerns the stages of our research and the related comments.

Starting with $R Q 1$, Figure 1 emphasises the percentage of net loans to total assets of bank balance sheets in the period between 2005 and 2014. The data refer to the mean of the sample for each year.

Figure 1 The impact of net loans to total assets

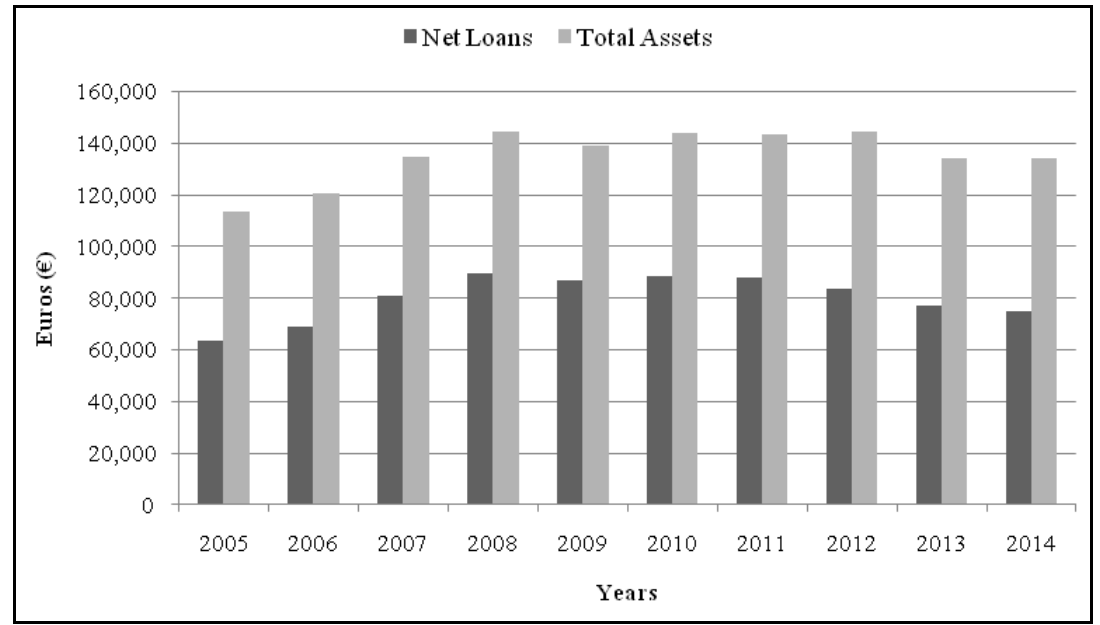

The figure confirms our first hypothesis. Therefore, in the sample of banking firms considered, it can be remarked that the gross loans were a significant part of the total assets.

Moreover there was a direct correlation between the two. In fact when gross loans went up, total assets increased too.

Obviously, the trend of total assets was also influenced by other items such as financial assets, classified as available for sale (AFS) or held for trading (HFT).

Moreover, despite the crisis in the period between 2007 and 2009, the sample of Italian banks increased its gross loans, contrary to what happened in the sample of US banks (Keister and McAndrews, 2009).

Figure 2 instead shows the trend of gross loans and reserves for impaired loans during the same period. The data refer to the mean of the sector for each year.

The two figures demonstrate that the initial first hypothesis is true. In addition, it is important to understand the relationship in the balance sheets of banks between credits and the reserves.

By analysing their evolution, we can state that the two items were interrelated in the period considered. We can notice that the reserves gradually increased between 2005 and 2013, while credits did not have the same steady growth. In 2009, the increase stopped and then started growing again, but in 2011 the amount of gross loans began falling. It is therefore clear that in a period of crisis, such as the one that we have been through, banks have increased their reserves for impaired loans and have decided to reduce their risks. 
Figure 2 The trend of gross loans and reserves for impaired loans

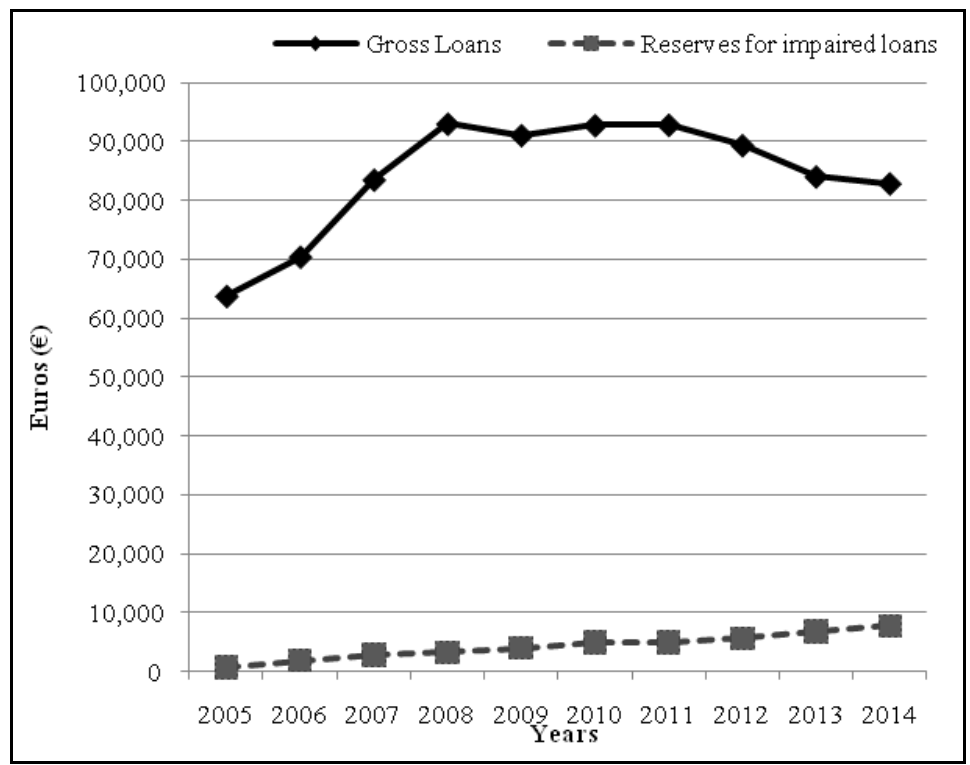

Table 3 shows the percentage of impaired loans to gross loans, referring to the sample analysed. As we can see, the amount of reserves has increased over the years. In fact it passed from $2.6 \%$ in 2005 to $7.37 \%$ in 2014 .

In particular, in 2008 there was a peak, clearly determined by the general situation of crisis of that year and the reserves started growing again in 2012.

Table 3 The percentage of reserves for impaired loans to gross loans of the banks of the sample

\begin{tabular}{lcccccccccc}
\hline & 2005 & 2006 & 2007 & 2008 & 2009 & 2010 & 2011 & 2012 & 2013 & 2014 \\
\hline $\begin{array}{l}\text { Reserves of } \\
\text { impaired loans }\end{array}$ & $2.6 \%$ & $2.5 \%$ & $3.3 \%$ & $4.4 \%$ & $3.1 \%$ & $3.4 \%$ & $3.9 \%$ & $4.9 \%$ & $6.4 \%$ & $7.37 \%$ \\
\hline
\end{tabular}

In order to answer $R Q 2$, we calculated the Pearson correlation ratio between loan growth, bank solvency and loan losses and the interest income of each bank.

Table 4 shows the results deriving from the Pearson correlation ratio calculated in 2014.

The present table confirms there is a positive moderate correlation between the natural logarithm of loan loss provisions and the variation of the related interest income.

In addition, we can confirm our $H 2$, because Table 4 underlines a strong negative correlation between loan growth and the variation of the related interest income.

Consequently, because of this inversely proportional relation, new loans that have been granted in order to abnormally expand a bank's credit portfolio are priced at a lower rate than loans granted by banks that intend to maintain their current credit exposure.

However, there is no correlation between equity-to-total assets and the variation of the related interest income. 
Table 4 The correlation between loan growth, bank solvency and loan losses and the interest income of the banks of the sample

\begin{tabular}{llcccc}
\hline & & $\Delta R I I$ & $L G$ & EQASS & LNLLPROV \\
\hline Pearson & $\Delta$ RII & 1.000 & -.639 & .000 & .463 \\
correlation ratio & LG & -.639 & 1.000 & .077 & -.482 \\
& EQASS & .000 & .077 & 1.000 & -.417 \\
& LNLLPROV & .463 & -.482 & -.417 & 1.000 \\
Sign. (1-tailed) & $\Delta$ RII &. & .003 & .500 & .031 \\
& LG & .003 &. & .384 & .025 \\
& EQASS & .500 & .384 &. & .048 \\
& LNLLPROV & .031 & .025 & .048 &. \\
& $\Delta$ RII & 17 & 17 & 17 & 17 \\
& LG & 17 & 17 & 17 & 17 \\
& EQASS & 17 & 17 & 17 & 17 \\
& LNLLPROV & 17 & 17 & 17 & 17 \\
\hline
\end{tabular}

Table 5 The results of the multivariate regression

\begin{tabular}{lcc}
\hline Dep. var.: $\triangle R I I_{i, t}$ & & \\
\hline Explanatory var. & Coeff. & p-value \\
\hline LG &,$- 516^{* * *}$ & .047 \\
& $(.354)$ & .504 \\
EQASS & .156 & .301 \\
& $(.014)$ & \\
LNLLP & .279 & .180 \\
& $(.019)$ & \\
Constant & $-.273^{* * *}$ & \\
& $(.193)$ & \\
No. of banks & 17 & \\
$\mathrm{R}$ & .677 & \\
$\mathrm{R}^{2}$ & .459 & \\
Adj. $\mathrm{R}^{2}$ & .334 & \\
\hline
\end{tabular}

Notes: The dependent variable is the absolute change from the year $t-1$ to t of bank $i$ 's relative gross interest income $\left(R I I_{i, t}\right)$, defined as the fraction of total interest income in $\mathrm{t}$ over the average of total customer loans in $t-1$ and $t$. Explanatory variables are the contemporaneous loan growth $\left(L G_{i, t}\right)$, the equity-to-total assets ratio $\left(E Q A S S_{i, t}\right)$ and the natural logarithm of loan loss provisions $\left(L N L L P_{i, t}\right)$. $* * *, * *, *$ Indicate that coefficients are statistically significant at $1 \%, 5 \%$ and $10 \%$-level.

With reference to $R Q 3$, the MANOVA regression model, explained in the previous paragraph, is based on the following null and alternative hypothesis:

$$
\begin{aligned}
& H_{0}: \beta_{1}=\beta_{2}=\beta_{3}=0 \\
& H_{1}: \beta_{1} \neq \beta_{2} \neq \beta_{3} \neq 0
\end{aligned}
$$


Table 5 summarises the results derived from the application of the model in the group of banks.

The MANOVA regression model explains approximately $50 \%$ of the entire sample $\left(\mathrm{R}^{2}=0.459\right)$. The null hypothesis can be rejected because all the coefficients are not equal to zero. We detect a negative and a highly significant impact of loan growth (LG) on the variation of the relative interest income.

Loan growth is the only variable that explains in an appropriate way the generalised model.

The other independent variables, equity-to-total assets (EQ.ASS) and the natural logarithm of loan loss provisions (LNLLP) are not statistically significant.

The problem might be due to the fact that the MANOVA analysis refers to only one year of observation. As mentioned in previous paragraphs, that is one of the limits of this research.

It could be interesting to study the impact of the variables implied in our research on the profitability of banks belonging to other counties or to extend the multivariate regression to other years.

In conclusion, thanks to our multivariate analysis of regression we can confirm again our second hypothesis ( $\mathrm{H} 2$ ): loan growth leads to a decrease in the relative interest income of the banks of the sample. Consequently, we answered our third research question $(R Q 3)$.

\section{Discussions}

Our research and its results confirm what many previous studies stated before: the gross loans are an essential item of the balance sheet, reaching in some years a percentage on average more than $50 \%$ of total assets (Keister and McAndrews, 2012). Consequently, we tested and confirmed our first hypothesis.

Nowadays the balance sheet of banks consists mainly of such item. But precisely for these reasons reserves for impaired loans have had an increasing importance.

Indeed, provisions to reserves for impaired loans reveal that they will be one of the most strategic items of bank balance sheets. Under these provisions, administrators will influence the income statement of the bank.

Our findings raise an important bank supervisory policy issue: the use of bank level variables as early warning indicators.

Thanks to our study, we realised that in Italy in the period between 2005 and 2014 the gross loans of the group of banks considered increased. Moreover the related reserves for impaired loans had the same trend.

As a consequence the recent crisis has generated strong concern regarding gross loans.

This system thus brought to an increase of provisions to reserves for impaired loans.

With reference to our second hypothesis $(H 2)$, we have noticed that the Pearson correlation ratio underlines that there is a strong negative correlation between loan growth and the variation of the related interest income. Therefore, because of this inversely proportional relation, new loans that have been granted in order to abnormally expand a bank's credit portfolio were priced at a lower rate than loans granted by banks that intend to maintain their current credit exposure. In addition, there was a positive 
moderate correlation between the natural logarithm of loan loss provisions and the variation of the related interest income.

However, there was no correlation between equity-to-total assets and the variation of the related interest income.

These findings are also confirmed by the MANOVA regression model, in fact we detected a negative and a highly significant impact of loan growth (LG) on the variation of the relative interest income. As a consequence, loan growth is the only variable that explains in an appropriate way the generalised model.

The other independent variables, equity-to-total assets (EQ.ASS) and the natural logarithm of loan loss provisions (LNLLP) are not statistically significant.

Consequently, we can confirm what previous important studies underlined: loan growth affects the riskiness of individual banks in many countries (Bushman and Williams, 2012; Foos et al., 2010). Moreover what Foos et al. underlined, by using different multivariate regression models, is true: loan growth leads to a decrease in the related interest income. All these findings lead to the conclusion that loan growth is an important driver of the riskiness of banks.

\section{Conclusions}

This study focuses on the relationship between gross loans and the related reserves for impaired loans of the group of banks listed on the Italian Stock Exchange between 2005 and 2014.

In our empirical research we analysed the trend of those items and we also concentrated on the impact of net loans on total assets.

Afterwards we monitored the correlation between loan growth, bank solvency, loan losses and the interest income of each bank in order to analyse the impact on the profitability of the banks and evaluate the effects of a specific loan policy.

Finally we concentrated on the multivariate linear regression, whose dependent variable is the variation of the interest income between 2013 and 2014.

With our model of multivariate regression, we wanted to improve one of Foos et al.'s model in order to adapt it to Italian listed banks.

Data were extracted from a database, called Bankscope, which is a database containing comprehensive information on financial companies (banks and insurance companies) in Italy.

Our research raises important issues on the necessary policy supervision in terms of risk management because, thanks to our analysis, we underline the strategic role of loan growth and its impact on the economic profitability of Italian listed banks.

What we have analysed also allowed us to introduce all the limits of this research. First of all, this study represents the second step of a much deeper analysis that can consider other variables, financial indicators and margins. We decided not to use an extremely complex multivariate model of regression because we aimed at pursuing the effectiveness of the results and concentrating on the real relationship between the items considered.

One of the future developments is to extend the same analysis to other banks belonging to different countries with the aim to compare and contrast the Italian situation with that of other realities. In addition, it could be interesting to extend the MANOVA 
analysis of regression to other years in order to evaluate the inter-temporal relationship of the variables implied in our study.

This research has also other implications in fact the elements analysed are strictly linked to the analysis of the riskiness of a bank. Banks should carefully check whether the additional income generated by an increase in lending represents an adequate compensation for the additional risk they would take. Bank supervisors and deposit insurers may benefit from monitoring a set of individual bank loan growth indicators to obtain early warning signals about the riskiness of banks.

In the future we could extend our study by analysing the effects of bank growth on bank risks.

Moreover the overall situation has also an impact on the topic of bank mergers. Business combinations would bring benefits in terms of aggregate credit risk and its management.

\section{References}

Acharya, V., Saunders, A. and Hassan, I. (2003) Should Banks be Diversified? Evidence from Individual Bank Loan Portfolios, September 2002, BIS Working Paper No. 118, AFA 2003 Washington, DC Meetings, London Business School, NYU Stern School of Business working paper, SSRN [online] http://ssrn.com/abstract=293295 (accessed 20 January 2015).

Ali, A. and Ansari, I.A. (2007) 'Financial sector reforms and soundness of banks operating in Pakistan', Journal of Management and Social Sciences, Vol. 3, No. 2, pp.63-69.

Álvarez, V.A. and Rossignolo, A.F., (2015) 'Análisis Comparativo De Técnicas (IMA) Para Determinar Capitales Mínimos Regulados Por Basilea, Ante Crisis En Mercados Emergentes' [Comparative analysis of techniques (IMA) for determining minimum capital regulated by Basel, facing crises in emerging markets], ODEON, Vol. 8, pp.13-14, Social Science Research Network (SSRN) [online] http: //ssrn.com/abstract $=2566754$ (accessed 15 March 2015).

Angelini, P., Clerc, L., Cúrdia, V., Gambacorta, L., Gerali, A., Locarno, A., Motto, R., Roeger, W., van den Heuvel, S. and Vlček, J. (2011) Basel III: Long-Term Impact on Economic Performance and Fluctuations, Federal Reserve Bank of New York Staff Report, p.485.

Avdjie, S., Zsolt, K. and Elöd, T. (2012) 'The euro area crisis and cross-border bank lending to emerging markets', BIS Quarterly Review, December, No. 4, pp.37-47.

Barros, C.P., Ferreira, C. and Williams, J. (2007) 'Analyzing the determinants of performance of best and worst European banks', Journal of Banking and Finance, Vol. 31, No. 7, pp.2189-2203.

Berger, A. and Udell, G. (2004) 'The institutional memory hypothesis and the procyclicality of bank lending behavior', Journal of Financial Intermediation, Vol. 13, No. 4, pp.458-495.

Berger, A.N. (2005) 'Corporate governance and bank performance: a joint analysis of the static, selection, and dynamic effects of domestic, foreign, and state ownership', Journal of Banking \& Finance, Vol. 29, Nos. 8-9, pp.2179-2221.

Berger, A.N. and de Young, R. (1997) 'Analyzing the determinants of performance of best and worst European banks', Journal of Banking and Finance, Vol. 21, No. 6, pp.849-870.

Bikker, J. and Metzemakers, P. (2005) 'Bank provisioning behaviour and procyclicality', Journal of International Financial Markets, Institutions, and Money, Vol. 15, No. 2, pp.141-157.

Bocchino, U., Ossola, G., Giovando, G. and Venuti, F. (2013) Il bilancio delle banche, Giuffrè, Milano.

Borio, C. (2008) The Financial Turmoil of 2007. A Preliminary Assessment and Some Policy Considerations, BIS Working Papers No. 251. 
Boubakri, N.C, Fischer, K. and Guedhami, O. (2005) 'Privatization and bank performance in developing countries', Journal of Banking and Finance, Vol. 29, Nos. 8-9, pp.2015-2041.

Bushman, R.M. and Williams, C.D. (2012) 'Accounting discretion, loan loss provisioning, and discipline of Banks' risk-taking', Journal of Accounting and Economics, Vol. 54, No. 1, pp.1-18.

Busso, D. (2014) 'IAS 39', in Dezzani, F., Biancone, P.P. and Busso, D. (Eds.): IAS/IFRS, IPSOA, Milano.

Caprio, G., Klingebiel, D., Laeven, L. and Noguera, G. (2005) 'Appendix: banking crisis database', in Honohan, P. and Laeven, L. (Eds.): Systemic Financial Crises: Containment and Resolution, Cambridge University Press, Cambridge, UK.

Clair, R. (1992) 'Loan growth and loan quality: some preliminary evidence from Texas banks', Federal Reserve Bank of Dallas Economic Review, Third Quarter, pp.9-22 [online] http://www.dallasfed.org/assets/documents/research/er/1992/er9203b.pdf (accessed 30 November 2014).

Cosimano, T.F. and Hakura, D. (2011) Bank Behaviour in Response to Basel III: A Cross-Country Analysis, IMF Working Paper No. 11/119, 34 pp., SSRN http://ssrn.com/abstract=1860182 or http://dx.doi.org/10.2139/ssrn.1860182, ISSN 9781455262427/1018-5941.

Cottarelli, C., Dell'Ariccia, G. and Vladkova-Hollar, I., (2005) 'Early birds, late risers, and sleeping beauties: bank credit growth to the private sector in Central and Eastern Europe and in the Balkans', Journal of Banking and Finance, Vol. 29, No. 1, pp.83-104.

Crowley, J. (2015) Central and Commercial Bank Balance Sheet Risk Before, during and after the Global Financial Crisis, International Monetary Funds, IMF Working Paper WP/15/47, 54 pp., ISSN 9781475564273/1018-5941.

Dell'Ariccia, G., Igan, D. and Laeven, L. (2008) Credit Booms and Lending Standards: Evidence from the Subprime Mortgage Market, IMF Working Papers 08/106.

Dezzani, F., Biancone, P.P. and Busso, D. (2014) IAS/IFRS, IPSOA, Milano.

Elliott, D.J. (2009) Quantifying the Effects on Lending of Increased Capital Requirements, Brookings briefing paper, Brookings Institution, Washington, DC.

Faisal, M.T. and Farzand, A.J. (2015) 'Financial performance of banks in Pakistan: a comparative analysis of public and private sectors', VFast Transactions on Education and Social Sciences, Vol. 6, No. 2, pp.2309-3951.

Ferrero, G. (1987) Impresa e management, Giuffrè, Milano.

Foos, D., Norden, L. and Weber, M. (2010) 'Loan growth and riskiness of banks', Journal of Banking and Finance, Vol. 34, No. 12, pp.2929-2940.

Giovando, G. (1996) 'La banca', in AA.VV.: Lezioni di Economia Aziendale, Giuffrè, Milano.

Giovando, G. and Gianoglio, G. (1999) 'Le banche', in AA.VV.: Euro ed Economia Aziendale, Giuffrè, Milano.

Giovando, G. and Venuti, F. (2014) 'The evolution of Italian insurers' assets book value', Conference Readings Book Proceedings. 7th Euromed Conference of the EuroMed Academy of Business 'The Future of Entrepreneurship', ISI Proceedings SM, Euromed Press, Kristiansand, Norway.

Hartvigsen, G. (1992) 'Limitations of knowledge-based systems for financial analysis in banking', Expert Systems with Applications, Vol. 4, No. 1, pp.19-32.

Iannotta, G., Nocera, G. and Sironi, A. (2007) 'Ownership structure, risk and performance in the European banking industry', Journal of Banking and Finance, Vol. 31, No. 7, pp.2127-2149.

Illueca, M., Norden, L. and Udell, G., (2008) 'Liberalization, corporate governance, and savings banks', EFA 2008 Athens Meetings Paper.

Iqbal, J. and Raza, G. (2009) Building Global Banks: A Comparative Analysis of European Banks over Time, Cambridge University Press, Cambridge, UK. 
Kahlert, D. and Wagner, N. (2015) Are Eurozone Banks Undercapitalized? A Stress Testing Approach to Financial Stability. A Stress Testing Approach to Financial Stability, Working paper, SSRN [online] http://ssrn.com/abstract=2568614 orhttp://dx.doi.org/10.2139/ ssrn.2568614 (accessed 17 December 2015).

Keister, T. and McAndrews, J.J. (2009) 'Economics and finance', Monetary Economics eJournal, Vol. 15, No. 8, pp.24-26.

Koch, T. and MacDonald, S. (2007) Bank Management, 7th ed., South-Western Cengage Learning, Marson, Ohio.

Kraft, E. and Jankonov, L. (2005) 'Does speed kill? Lending booms and their consequences in Croatia', Journal of Banking and Finance, Vol. 29, No. 1, pp.105-121.

Laeven, L. and Majnoni, G. (2003) 'Loan loss provisioning and economic slowdowns: too much, too late?', Journal of Financial Intermediation, Vol. 12, No. 2, pp.178-197.

Laeven, L. and Valencia, F. (2008) Systemic Banking Crisis: A New Database, IMF Working Paper 8-224, International Monetary Fund, Washington, DC.

Navajas, C.M. and Thegeya A. (2013) Financial Soundness Indicators and Banking Crises, IMF Working Paper WP/13/XX, forthcoming.

Onado, M. (2000) Mercati e intermediari finanziari. Economia e regolamentazione, Il Mulino, Bologna.

Ossola, G. (2000) I bilanci degli enti finanziari, Giuffrè, Milano.

Ossola, G. (2005) Gli schemi del bilancio d'esercizio degli enti creditizi, Giuffrè, Milano.

Salas, V. and Saurina, J. (2002) 'Credit risk in two institutional regimes: Spanish commercial and savings banks', Journal of Financial Services Research, Vol. 22, No. 3, pp.203-224.

Sinkey, J. and Greenwalt, M. (1991) 'Loan-loss experience and risk-taking behavior at large commercial banks', Journal of Financial Services Research, Vol. 5, No. 1, pp.43-59.

Strahanb, P.E. and Cebenoyan, S.A. (2004) 'Risk management, capital structure and lending at banks', Journal of Banking and Finance, Vol. 28, No. 1, pp.19-43. 